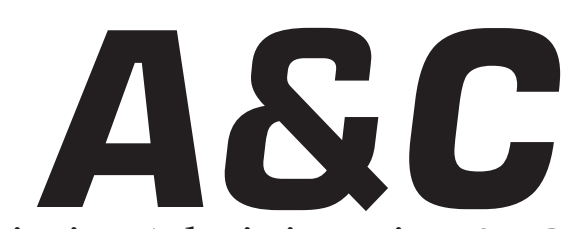

Revista de Direito Administrativo \& Constitucional

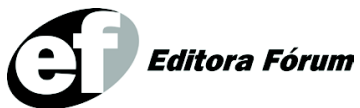

ISSN 1516-3210

A\&C R. de Dir. Administrativo e Constitucional Belo Horizonte ano 8 n. 31 p. 1-272 jan./mar. 2008 


\section{A\&C - REVISTA DE DIREITO ADMINISTRATIVO E CONSTITUCIONAL}

IPDA

Instituto Paranaense

de Direito Administrativo

Direção Geral

Romeu Felipe Bacellar Filho

Direção Editorial

Paulo Roberto Ferreira Motta

Direção Executiva

Emerson Gabardo

Conselho de Redação

Edgar Chiuratto Guimarães

Adriana da Costa Ricardo Schier

Célio Heitor Guimarães

\section{Conselho Editorial}

Adilson Abreu Dallari

Alice Gonzáles Borges

Carlos Ari Sundfeld

Carlos Ayres Britto

Carlos Delpiazzo

Cármen Lúcia Antunes Rocha

Celso Antônio Bandeira de Mello

Clèmerson Merlin Clève

Clóvis Beznos

Enrique Silva Cimma

Eros Roberto Grau

Fabrício Motta

Guilhermo Andrés Muñoz (in memoriam)

Jaime Rodríguez-Arana Muñoz

Jorge Luís Salomoni

José Carlos Abraão
José Eduardo Martins Cardoso
José Luís Said
José Mario Serrate Paz
Juan Pablo Cajarville Peruffo
Juarez Freitas
Julio Rodolfo Comadira
Luís Enrique Chase Plate
Lúcia Valle Figueiredo
Manoel de Oliveira Franco Sobrinho
(in memoriam)
Marçal Justen Filho
Marcelo Figueiredo
Márcio Cammarosano
Maria Cristina Cesar de Oliveira

Nelson Figueiredo

Odilon Borges Junior

Pascual Caiella

Paulo Eduardo Garrido Modesto

Paulo Henrique Blasi

Paulo Neves de Carvalho (in memoriam)

Paulo Ricardo Schier

Pedro Paulo de Almeida Dutra

Regina Maria Macedo Nery Ferrari

Rogério Gesta Leal

Rolando Pantoja Bauzá

Sérgio Ferraz

Valmir Pontes Filho

Yara Stropa

Weida Zancaner

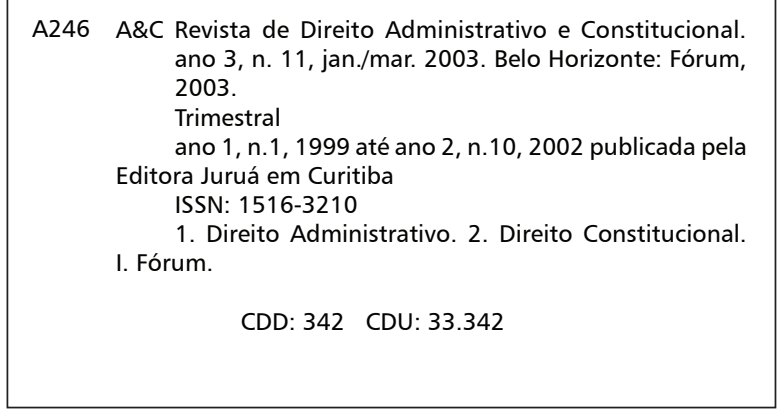

(c) Editora Fórum Ltda. 2008

Todos os direitos reservados. É proibida a reprodução total ou parcial, de qualquer forma ou por qualquer meio eletrônico ou mecânico, inclusive através de processos xerográficos, de fotocópias ou de gravação, sem permissão por escrito do possuidor dos direitos de cópias (Lei $n^{\circ}$ 9.610, de 19.02.1998).

Editora Fórum Ltda.

CEP 30130-007 - Belo Horizonte/MG - Brasil

Tel.: 08007043737

Internet: www.editoraforum.com.br

e-mail: editoraforum@editoraforum.com.br
Av. Afonso Pena, 2770 - 15\%/16 andar - Funcionários

Editor responsável: Luís Cláudio Rodrigues Ferreira

Coordenação editorial: Olga M. A. Sousa

Projeto gráfico e diagramação: Luis Alberto Pimenta

Revisoras: Carolina Rocha

Lourdes Nascimento

Pesquisa jurídica: Fátima Ribeiro - OAB/MG 74868

Bibliotecárias: Fernanda de Paula Moreira

Leila Aparecida Anastácio - CRB 2513 - 6ª região

Os conceitos e opiniões expressas nos trabalhos assinados são de responsabilidade exclusiva de seus autores.

Impressa no Brasil / Printed in Brazil

Distribuída em todo o Território Nacional 


\title{
La Constitución Nacional y su incidencia en la organización de la Administración Pública Nacional en la República Argentina
}

\begin{abstract}
Miriam Mabel Ivanega
Abogada, Magister en derecho administrativo de la Universidad Austral, profesora de las Universidades Nacional de Buenos Aires, Católica de Buenos Aires, Austral, Nacional del Comahue, Nacional de Rosario, entre otras. Profesora invitada de la Universidad Simon Bolivar de La Paz, Bolivia. Miembro del Instituto de Derecho Administrativo de la Academica Nacional de Derecho. Es Directora Ejecutiva de la Maestría en derecho adminsitrativo y de la Especialización en Derecho de la Regulación de servicios públicos. Ha dictado numerosas conferencias y cursos en el interior del país y en el exterior. Es autora de diversos artículos jurídicos; capítulos en obras colectivas y de tres libros vinculados a la temática de la organización de la Administración Pública, el control y los servicios públicos.
\end{abstract}

Palabras clave: Administración Pública. Constitución Argentina. Los Ministros.

Índice: Sobre las diversas formas de gobierno, véase a PAOLO BISCARETTI DI RUFFÍA, ob. cit., p. 153 y ss.e: I Introducción. La Administración Pública - II El Estado federal y su incidencia en el derecho administrativo - III Derechos y garantías fundamentales. Usuarios y consumidores. El principio de participación - IV El Poder Ejecutivo y el Jefe de Gabinete de Ministros: División entre titularidad y gestión de la función administrativa. Los Ministros - V Los Entes Reguladores de servicios públicos - VI Organismos de control de la Administración Pública previstos en la Constitución Nacional

- VII El presupuesto

\section{Introducción. La Administración Pública}

Es indudable que la fuente primaria del derecho administrativo y de todas las ramas del derecho es la Constitución Nacional.

Las bases de la administración como función y organización se encuentran en esos preceptos. El artículo $31 \mathrm{CN}$ da muestras de ello al expresar: Esta Constitución, las leyes de la Nación que en su consecuencia se dicten por el Congreso y los tratados con las potencias extranjeras son la ley suprema de la Nación; y las autoridades de cada provincia están obligadas a conformarse a ella, no obstante cualquiera disposición en contrario que contengan las leyes o Constituciones provinciales, salvo para la Provincia de Buenos Aires, los tratados ratificados después del pacto del 11 de noviembre de 1859.

El derecho administrativo se desarrolla a partir de la separación de poderes, de los límites propios del Estado de Derecho y del reconocimiento 
de derecho y garantías. Por eso, como bien ha enseñado Bielsa tiene el encabezamiento de sus capítulos en la Constitución. ${ }^{1}$

Algunos autores incluso, llegan a sostener que la separación entre el derecho constitucional y el administrativo es artificiosa y que demarcar sus límites resulta innecesario.

La idea de un derecho administrativo dinámico frente a un derecho constitucional estático implica que éste conoce sobre los rasgos de la organización política y social de un país; mientras que el derecho administrativo enseña a poner en funcionamiento y a recoger los resultados. De ahí que el derecho constitucional constituya su espina dorsal. ${ }^{2}$

La Constitución Argentina está compuesta por el Preámbulo; se divide en dos Partes compuesta por Secciones y Capítulos. La primera parte contiene las declaraciones, derechos y garantías; la segunda trata de las autoridades de la Nación.

La reforma del año 1994 incorporó los llamados derechos de la tercera generación (de usuarios y consumidores y de protección del ambiente) amplió las garantías personales y colectivas, reconoció la diversidad personal, social, étnica, educativa, cultural, política, electoral y económica y trazó nuevos perfiles del Estado. ${ }^{3}$

También introdujo la figura del Jefe de Gabinete de Ministros y la de determinados organismos de control y fijó los límites y condiciones a las que debe sujetarse el Poder Ejecutivo en el dictado de los reglamentos delegados y de necesidad y urgencia.

Vamos a abordar el vínculo entre la Constitución y el derecho administrativo, respecto a la organización administrativa, advirtiendo la imposibilidad de analizar todas las consecuencias que de ella se derivan.

En realidad, principios, derechos, deberes, prerrogativas, organismos, acciones judiciales condicionan la estructura y la organización de la Administración Pública. Su carácter necesario emana de la propia de la Constitución, que brinda el marco de actuación en cuanto límite y extensión, a partir de los principios democráticos y de las bases del Estado de Derecho.

La Administración Pública es la pieza arquitectónica organizativa del Estado y por ende un instrumento esencial para la realización efectiva del

\footnotetext{
Bielsa, Rafael Derecho Administrativo, T. I, 6. ed., Buenos Aires, 1964, p. 144.

Diez Manuel M., Derecho Administrativo, OMEBA, T. I, Buenos Aires, 1963, p. 319 y ss. Sayagues Laso considera incluso que nos encontramos en un proceso de constitucionalización del derecho administrativo. Sayagues Laso, Tratado de derecho administrativo, T. I, Montevideo, 1987, p. 90 y ss.

3 Gelli María A., Constitución de la Nación Argentina comentada y concordada, 2. ed. actualizada, La Ley, Buenos Aires, 2003, p. 314.
} 
orden constitucional. ${ }^{4}$ Se sujeta al entorno constitucional, como condición fundamental para su validez, obligatoriedad y eficacia. ${ }^{5}$

La organización siempre deberá responder a los lineamientos de la Ley Fundamental, a fin de asegurar la tutela de los derechos y garantías individuales. Es así que, el diseño de la estructura administrativa ha de ajustarse a los requerimientos sociales e individuales que debe satisfacer.

Nuestra Constitución Nacional no contiene preceptos expresos acerca de la organización administrativa o a los principios de la Administración Pública. Sin embargo, es indudable que la actividad que desarrolla y su sentido teleológico la obligan a ordenarse a hacia sus objetivos.

Sí se hace referencia a la Administración general del país, en los artículos 99 y 100, vinculados a las competencias del Poder Ejecutivo y del Jefe de Gabinete de Ministros.

Como fuente de competencia, conforma las principales características y forma de actuación de autoridades administrativas (Presidente de la Nación, Jefe de Gabinete y Ministros), reconoce las garantías y derechos que la Administración debe respetar y proteger, las acciones con que cuentan los particulares frente a la ilegitimidad o arbitrariedad de las autoridades, incluye instrumentos esenciales para el funcionamiento de la Administración como por ejemplo la ley de presupuesto y régimen de coparticipación (artículo $75 \mathrm{CN}$ ) y prevé organismos que controlan el accionar administrativo (Auditoría General de la Nación y Defensoría del Pueblo, arts.85 y $86 \mathrm{CN})$.

Algunas de las instituciones previstas en la Constitución relacionadas con la organización administrativa, que serán citadas en este trabajo; son:

- La estructura federal del Estado

- El reconocimiento de todos los principios y garantías individuales y sociales

- La formación y competencias del Poder Ejecutivo, Jefe de Gabinete de Ministros y Ministros

- Los Entes Reguladores de Servicios Públicos

- Los Organismos de Control

- El presupuesto

\footnotetext{
Parejo Alfonso Luciano, Manual de derecho administrativo, Ariel, Barcelona, 1992.

5 Escola Héctor, Compendio de derecho administrativo. V.I., Depalma, Buenos Aires, 1990, p. 67.
}

A \& C R. de Dir. Administrativo \& Constitucional, Belo Horizonte, ano 8, n. 31, p. 150-179, jan./mar. 2008 


\section{El Estado federal y su incidencia en el derecho administrativo 1 El Estado Federal}

Hay tanto federalismo como naciones federales existen. Este pensamiento de Matienzo resume perfectamente la imposibilidad de buscar uniformidad en este sentido.

Como indica Salomoni, la originalidad de nuestra Constitución se refleja en la originalidad del derecho público que prevaleció más allá de las modas circunstanciales. Y ello es así porque la Constitución es tributaria del Proyecto redactado por Juan Bautista Alberdi. ${ }^{6}$

El federalismo argentino no es el norteamericano, ni el suizo, ni el alemán. Alberdi se refería a una unidad-federativa o de una federación-unitaria. La historia argentina, de la mano de las situaciones geográfica, social, cultural, religiosa, más causas políticas marcan las características de nuestro federalismo. ${ }^{7}$

La Constitución consagra: "La Nación Argentina adopta para su forma de gobierno la forma representativa republicana federal". ${ }^{8}$

El fundamento del Estado federal es la pluralidad de centros soberanos coordinados entre sí e $^{\mathrm{e}}$ implica la división del poder entre el gobierno federal y los gobiernos locales.

Operan dos fuerzas opuestas, que procuran superarse y vencerse en forma recíproca y sobre cuyo equilibrio - que en los hechos nunca se logra-se funda todo el esquema del federalismo. Hay una fuerza centrípeta y concentradora que atrae, dirige e impele hacia el centro (en el caso el gobierno general) y una centrífuga o desconcentradora, que atrae, dirige e impele en sentido contrario al centro (los gobiernos locales) "la dinámina federal se manifiesta en una lucha permanente entre ambas fuerzas". ${ }^{10}$

El Estado central tiene una soberanía separada de la que corresponde a los Estados miembros; la distribución de competencia entre ellos se hace respetando esa delimitación.

\footnotetext{
6 Salomoni Jorge L. Palabras de Apertura a las Jornadas Nacionales de Derecho Administrativo de la AADA, agosto de 2003, p. 7 y ss.

7 Ver Pérez Guilhou Dardo, Historia de la originalidad constitucional argentina, Depalma, Buenos Aires, 1994c.

8 Si bien la Constitución no diferencia la forma de gobierno de la forma de Estado, puede afirmarse "que la primera responde a la pregunta sobre quien ejercita el poder y la segunda acerca de cuántos centros territoriales de decisión política existen en un Estado", Gelli María Angélica Constitución de la Nación Argentina comentada y concordada, 2. ed. actualizada, La Ley, Buenos Aires, 2003, p. 16.

9 Bidart Campos Germán, Manual de la Constitución reformada, T. III, Ediar, Buenos Aires, 1997, p. 739.

10 Linares Quintana Segundo V., Tratado de la Ciencia del derecho constitucional argentino y comparado, Plus Ultra, Buenos Aires, 1985, p. 318.
} 
El orden federal supone una Constitución escrita que da fundamento a las relaciones federales y establece un compromiso entre los intereses de la unidad nacional y de la autonomía regional. Los Estados miembros renuncian de ciertos derechos inherentes a su soberanía, a favor del Estado central. ${ }^{11}$

El sistema reconoce la preexistencia de las provincias y la reserva de todos los poderes que éstas no hubiesen expresamente delegado en el gobierno central, ${ }^{12}$ a la vez que exige aplicar estrictamente la preeminencia de los poderes federales en las áreas en que la Ley Fundamental así lo estableció. ${ }^{13}$

El federalismo encierra un reconocimiento y respeto hacia las provincias argentinas, ${ }^{14}$ pero esa identidad no encuentra su campo de realización solamente dentro del ámbito comprendido por los poderes no delegados sino también en el de la adecuación de sus instituciones a los requerimientos del artículo $5^{\circ}$, que indica:

Las Constituciones provinciales organizan a los gobiernos locales en base a las pautas consagradas por la Constitución nacional: a) la tipología de los gobiernos locales debe ser coherente con el establecido para el gobierno federal, b) la competencia de los gobiernos provinciales debe tomar en cuenta la distribución que esa norma efectúa entre el Estado federal y las provincias, c) los gobernadores de provincias son agentes naturales del gobierno federal para hacer cumplir la constitución y las leyes del Estado federal, d) deben respetar los artículos 31 y 75 inc. 22 de la CN.15

La soberanía pertenece al Estado federal, no a las provincias, las

\footnotetext{
11 Loewenstein Karl, Teoría de la Constitución, Ariel Ciencia Política, Barcelona, 1983, p. 325/326.

12 Comadira Julio R, Derecho administrativo, Lexis Nexis, Buenos Aires, 2002, p. 678. En ese sentido, el referido profesor - con cita de Germán Bidart Campos-señala que si bien las mayor parte de las provincias preexistieron históricamente al estado federal, éste, desde la perspectiva lógico jurídica, es anterior a las provincias, de modo que ésas derivan sus competencias de aquel. cita el criterio de la Corte Suprema de Justicia de la Nación (Fallos 308:1298 y 239:343) que reafirma la concepción de que de los términos del artículo 121 de la Constitución nacional no cabe inferir que las provincias se hayan reservado poderes, sino que ha sido la Constitución la que operó la distribución. Consecuencia de ello es que ni las legislaturas provinciales ni el Congreso nacional pueden modificar el reparto de competencias realizado por la Constitución.

13 Fallos 324:3048

14 El artículo 121 establece: Las provincias conservan todo el poder no delegado por esta Constitución al Gobierno Federal, y el que expresamente se hayan reservado por pactos especiales al tiempo de su incorporación.

15 Bidart Campos Germán, Tratado elemental de derecho constitucional argentino, T. I-A, EDIAR, Buenos Aires, 2000, p. 633.

16 Linares Quintana Segundo V., Tratado de la Ciencia del derecho cosntitucional argentino y comparado, Plus Ultra, Buenos Aires, 1985, p. 314; Bidart Campos, Germán, Tratado elemental..., op.cit., p. 632/633. La
} 
cuales son caracterizadas como autónomas. ${ }^{16}$

\section{Las relaciones entre el Estado nacional y las provincias}

Del referido régimen - que tiene perfiles propios que lo diferencian del modelo norteamericano-se derivan tres tipos de relaciones que traducen la delimitación de las competencias federales y provinciales: subordinación, participación, coordinación. ${ }^{17}$

La relación de subordinación se expresa en la supremacía federal por sobre las provincias, conforme a los artículos 5 y 31 de la Constitución Nacional ${ }^{18}$ El equilibrio entre el principio de unidad y el de pluralidad proporciona cohesión y armonía mediante la subordinación de los ordenamientos jurídico-políticos al ordenamiento federal, "para que las partes sean congruentes con el todo". Ello implica prioridad de la Constitución federal y de todo el orden jurídico federal". ${ }^{19}$

La relación de participación, es el reconocimiento de la colaboración de las provincias en la formación de las decisiones del gobierno federal. Está plasmada en la composición de la Cámara de Senadores, en ella está representada el equilibrio de los estados pequeños y grandes quienes defienden sus intereses y colaboran con el gobierno legislativo nacional. ${ }^{20}$

La coordinación se refiere a la distribución de competencias que se opera en el Estado federal, de forma tal que las funciones estatales son cumplidas por la acción coordinada de los organismos ambos gobiernos. ${ }^{21}$ Este tipo de vínculo permite delimitar las competencias del Estado federal y de las provincias. Se trata de distribuir las competencias de cada una de las esferas. ${ }^{22}$

Los poderes delegados al Gobierno Nacional son principalmente los vinculados con las atribuciones del Poder Legislativo y del Ejecutivo (artí-

soberanía es la cualidad del poder que, "al organizarse en forma jurídica y política, no reconoce dentro del ámbito de relaciones que rige, otro orden superior de cuya normación positiva derive lógicamente su propia validez normativa", op.cit., p. 632.

${ }^{17}$ Bidart Campos Germán, Tratado elemental...op.cit.; Gelli María A. Constitución de la Nación Argentina comentada y concordada, 2. ed. La Ley, Buenos Aires, 2003, p. 25.

18 "Artículo 5\%: Cada provincia dictará para sí una Constitución bajo el sistema representativo republicano, de acuerdo con los principios, declaraciones y garantías de la Constitución Nacional; y que asegure su administración de justicia, su régimen municipal, y la educación primaria. Bajo de estas condiciones, el Gobierno federal, garante a cada provincia el goce y ejercicio de sus instituciones."

${ }^{19}$ Bidart Campos Germán, Tratado elemental...op.cit., p. 650/651.

${ }^{20}$ Gelli María A. Constitución de la Nación Argentina..., p. 25.

${ }^{21}$ Linares Quintana Segundo V., Tratado de la Ciencia..., op.cit., p. 310.

22 Bidart Campos Germán, Tratado elemental...op.cit., p. 652. 
culos 75 y $99 \mathrm{CN}$ ); los reservados a las Provincias, surgen de los artículos $122,{ }^{23} 123^{24}$ y $124,{ }^{25}$ los concurrentes con el Estado federal, del artículo $125 ;{ }^{26}$ los prohibidos a las provincias son aquellos poderes que fueron delegados a la Nación según lo establecido en el artículo $126^{27}$ y los previstos en el artículo 127.28

En los casos expresamente previstos en el artículo 6 de la Constitución Nacional, el Gobierno Federal puede intervenir en el territorio de las provincias para garantizar la forma republicana de gobierno, o repeler invasiones exteriores y a requisición de sus autoridades para sostenerlas o restablecerlas en caso que hubiesen sido depuestas por sedición o invasión de otra provincia.

La intervención federal debe ser dispuesta por el Congreso Nacional, o el Poder Ejecutivo en caso de receso de aquel. ${ }^{29}$

Esta medida interesa al derecho administrativo en cuanto a la figura del interventor y su competencia; sus actos.

El interventor no es un órgano de la provincia, sino un delegado de

${ }^{23}$ Artículo 122: Se dan sus propias instituciones locales y se rigen por ellas. Eligen sus gobernadores, sus legisladores y demás funcionarios de provincia, sin intervención del Gobierno Federal.

${ }^{24}$ Artículo 123: Cada provincia dicta su propia constitución, conforme a lo dispuesto por el art. $5^{\circ}$ asegurando la autonomía municipal y reglando su alcance y contenido en el orden institucional, político, administrativo, económico y financiero.

25 Artículo 124: Las provincias podrán crear regiones para el desarrollo económico -social y establecer órganos con facultades para el cumplimiento de sus fines y podrán también celebrar convenios internacionales en tanto no sean incompatibles con la política exterior de la Nación y no afecten las facultades delegadas al Gobierno Federal o el crédito público de la Nación: con conocimiento del Congreso Nacional. La ciudad de Buenos Aires tendrá el régimen que se establezca a tal efecto. Corresponde a las provincias el dominio originario de los recursos naturales existentes en su territorio.

26 Artículo 125: Las provincias pueden celebrar tratados parciales para fines de administración de justicia, de intereses económicos y trabajos de utilidad común, con conocimiento del Congreso Federal; y promover su industria, la inmigración, la construcción de ferrocarriles y canales navegables, la colonización de tierras de propiedad provincial, la introducción y establecimiento de nuevas industrias, la importación de capitales extranjeros y la exploración de sus ríos, por leyes protectoras de estos fines, y con recursos propios. Las provincias y la ciudad de Buenos Aires pueden conservar organismos de seguridad social para los empleados públicos y los profesionales; y promover el progreso económico, el desarrollo humano, la generación de empleo, la educación, la ciencia, el conocimiento y la cultura.

27 Artículo 126: Las provincias no ejercen el poder delegado a la Nación. No pueden celebrar tratados parciales de carácter político; ni expedir leyes sobre comercio, o navegación interior o exterior; ni establecer aduanas provinciales; ni acuñar moneda; ni establecer bancos con facultad de emitir billetes, sin autorización del Congreso Federal; ni dictar los códigos Civil, Comercial, Penal y de Minería, después de que el Congreso los haya sancionado; ni dictar especialmente leyes sobre ciudadanía y naturalización, bancarrotas, falsificación de moneda o documentos del Estado; ni establecer derechos de tonelaje; ni armar buques de guerra o levantar ejércitos, salvo en el caso de invasión exterior o de un peligro tan inminente que no admita dilación dando luego cuenta al Gobierno Federal; ni nombrar o recibir agentes extranjeros.

28 Artículo 127: Ninguna provincia puede declarar, ni hacer la guerra a otra provincia. Sus quejas deben ser sometidas a la Corte Suprema de Justicia y dirimidas por ella. Sus hostilidades de hecho son actos de guerra civil, calificados de sedición o asonada, que el Gobierno Federal debe sofocar y reprimir conforme a la ley.

29 Artículo 75. "Corresponde al Congreso:....inciso 31): Disponer la intervención federal a una provincia o a la ciudad de Buenos Aires. Aprobar o revocar la intervención decretada, durante su receso, por el Poder Ejecutivo". Artículo 99. "El Presidente de la Nación tiene las siguientes atribuciones:....inciso 20): Decreta la intervención federal a una provincia o a la ciudad de Buenos Aires en caso de receso del Congreso, y debe convocarlo simultáneamente para su tratamiento."

30 Fallos 258:80.

A \& C R. de Dir. Administrativo \& Constitucional, Belo Horizonte, ano 8, n. 31, p. 150-179, jan./mar. 2008 
la Nación, con funciones administrativas de carácter conservatorio. ${ }^{30}$ Actúa como representante necesario del intervenido mientras se regulariza la situación de los poderes locales.

Pero sus actos son provinciales porque sustituye al gobernador y ejerce la competencia de éste conforme a la Constitución local. ${ }^{31}$ Estos actos dictados dentro de su competencia y conforme al ordenamiento provincial son válidos y obligan a la Provincia.

La impugnación de estos actos no es, por ende, competencia federal sino provincial. ${ }^{32}$

\section{Los Municipios}

La estructura federal se completa con los Municipios. El reconocimiento definitivo de su autonomía es producto de la reforma constitucional de 1994. El artículo 123 establece que "Cada provincia dicta su propia Constitución, conforme a lo dispuesto por el artículo $5^{\circ}$ asegurando la autonomía municipal y reglando su alcance y contenido en el orden institucional, político, administrativo, económico y financiero"

Cabe recordar que hasta 1994, la CN no establecía expresamente la naturaleza jurídica de los municipios. Su carácter autárquico o autónomo era objeto de discusiones doctrinarias y criterios jurisprudenciales.

El poder municipal es en realidad una reproducción del Estado federal y de las provincias y en las materias que caen en su jurisdicción pueden ejercitar una verdadera función legislativa de creación de derecho nuevo. ${ }^{33}$

La consagración constitucional de la autonomía municipal, obliga a las provincias. Sin embargo, como la $\mathrm{CN}$ no fija un único modelo de autonomía, se admite que puedan coexistir en una misma provincia municipios de convención (que posean atribuciones para dictar sus cartas autonómicas) y municipios reglados por leyes orgánicas sancionadas por las legislaturas provinciales.

El juego armónico de los artículos 5, 75 inc. 30 y 123 de la CN impone a las provincias la obligación de asegurar la autonomía municipal, la que presenta matices y modulaciones normativas variadas, pues por la autonomía política los municipios eligen a sus autoridades (base popular, electiva y democrática de esa organización); en el aspecto administrativo

\footnotetext{
31 Fallos 127:91.

32 Linares Juan F., Derecho Administrativo, Astrea, Buenos Aires, 2000, p. 272.

33 Tribunal Superior de Justicia de la Provincia de Córdoba causa "Cooperativa de Obras y Servicios de Río Ceballos Ltda. c/ Municipalidad de Río Ceballos s/acción de inconstitucionalidad del 16/05/2003.
} 
organizan su estructura de gobierno y la prestación de servicios públicos, sin interferencias de otras jurisdicciones estatales; por la autonomía económica y financiera tienen la potestad de recaudar e invertir los fondos; y en virtud de su aspecto institucional pueden dictar sus Cartas orgánicas. ${ }^{34}$

La autonomía municipal no es absoluta pues se hallan sujetas al régimen provincial, por eso se entiende que gozan de una autonomía de segundo grado.

La Constitución no reconoce poderes originarios a favor de los municipios ni tampoco poderes reservados, a diferencia de las provincias cuya autonomía es en este sentido, más amplia. La autonomía municipal prevista por la Constitución reformada posee una jerarquía diferente a la que ostentan las provincias. ${ }^{35}$

La estructura orgánica municipal es similar a la provincial: el Poder Ejecutivo está a cargo de un intendente y su organización administrativa no varía de la vigente en la provincia. El Poder Legislativo se atribuye a los Deliberantes y su función primordial es la dictar ordenanzas que regulan los aspectos municipales. En los municipios de mayor importancia existe el Tribunal de Faltas, a cuyo cargo se encuentra el juzgamiento de cuestiones menores (faltas y controversias municipales) que involucren a los administrados con el municipio. Sus decisiones son siempre revisables por la justicia provincial o nacional, según corresponda. ${ }^{36}$

\section{La Ciudad Autónoma de Buenos Aires}

El artículo 129 de la Constitución Nacional establece La ciudad de Buenos Aires tendrá un régimen de gobierno autónomo, con facultades propias de legislación y jurisdicción, y su jefe de gobierno será elegido directamente por el pueblo de la ciudad. Una ley garantizará los intereses del Estado nacional, mientras la Ciudad de Buenos Aires sea capital de la Nación....

La Ciudad sin alcanzar la categoría de provincia, posee un régimen autonómico que "de alguna manera, podemos ubicar entremedio del tradicional de las provincias y el propio de la autonomía municipal en

\footnotetext{
34 En ese sentido, Tribunal Superior de Justicia de la Provincia de Córdoba causa "Cooperativa de Obras y Servicios de Río Ceballos Ltda. c/ Municipalidad de Río Ceballos s/acción de inconstitucionalidad del 16/05/2003 con cita de Hernandez Antonio María (h), Derecho Municipal, 2. ed. Edición, Depalma, Buenos Aires 1997, p. 386.

35 Cassagne Juan Carlos, Derecho Administrativo, Lexis Nexis, Buenos Aires, 2003, T. I, p. 465

${ }^{36}$ Comadira Julio R., Derecho administrativo, Lexis Nexis, Buenos Aires, 2002, p. 723.

37 Comadira Julio R., Derecho administrativo...op.cit., p. 726/727.
} 
jurisdicción provincial”. ${ }^{37}$

Tiene una naturaleza jurídico-política particular, única, de origen constitucional y de carácter derivado.

El poder de ejercer una legislación exclusiva sobre el territorio de la capital de la República se mantiene incólume en cabeza del Congreso de la Nación (art. 75, inc. 30), potestad que la Constitución consagra como parte del régimen permanente del municipio capitalino, hallándose limitada por el principio de autonomía que consagra el artículo $129 .{ }^{38}$

La Constitución de la Ciudad sancionada en 1996, estructura a los poderes: el Ejecutivo a cargo del Jefe de Gobierno, del cual depende las Secretarías (que hacen las veces de ministerios) y demás organismos; el Legislativo es unicameral y el Judicial está formado por el Tribunal Superior de Justicia, el Ministerio Público, el fuero contencioso administrativo y tributario federal y el fuero en lo contravencional y de faltas.

Su Administración Pública tampoco difiere de la nacional, en cuanto a su estructura, aunque posee un importante programa de descentralización administrativa, mediante los Centros de Gestión y Participación (CGP) creados con el fin de agilizar la relación y el contacto inmediato con los vecinos. Los CGP son un canal de participación vecinal que, a través del protagonismo colectivo y la búsqueda de soluciones consensuadas, los convierte en una herramienta de control efectivo de la gestión de gobierno.

\section{El carácter local del Derecho Administrativo}

En resumen contamos con 4 niveles jurídico-institucionales: 1) Estado Federal; 2) Provincias; 3) Ciudad de Buenos Aires; 4) Municipios.

Y el carácter local del derecho administrativo es connatural del federalismo. La elaboración y dictado de las normas este derecho corresponde a la Nación o a las provincias, dentro de la órbita que a cada uno le fue asignada por la Constitución.

En cambio la legislación sustantiva o de fondo fue delegada por las provincias al Congreso federal. La Corte Suprema de Justicia ha insistido en que el respeto del sistema federal y de las autonomías provinciales requiere que se reserve a sus jueces el conocimiento y decisión de las causas que, en lo sustancial, versan sobre aspectos propios de su derecho público. ${ }^{39}$

\footnotetext{
38 Cassagne Juan C., Derecho administrativo...op.cit., p. 426/42.

39 Fallos 322:1514; 323:3270; 324:238.
}

A \& C R. de Dir. Administrativo \& Constitucional, Belo Horizonte, ano 8, n. 31, p. 150-179, jan./mar. 2008 
III Derechos y garantías fundamentales. Usuarios y consumidores. El principio de participación

\section{Los derechos fundamentales}

Los derechos fundamentales condicionan al Derecho administrativo y a toda la actividad administrativa en su conjunto, la que debe orientarse a la concreción efectiva de dichos derechos. ${ }^{40}$

El reconocimiento de derechos y libertades comprende las garantías jurídicas (penales, procesales, etc.), la efectiva realización material de exigencias políticas y éticas, públicas y privadas que se especifican como derechos económicos, sociales, culturales y que constituyen la base para la real dignidad y progresiva igualdad entre los seres humanos. ${ }^{41}$

El artículo 1.1. de la Convención Americana sobre Derechos Humanos, suscripta en San José de Costa Rica el 22 de noviembre de 1969 — con jerarquía constitucional conforme al artículo 75 inc. 22 de la Constitución Nacional-exige que los Estados partes respeten y garanticen el pleno y libre ejercicio de todos los derechos reconocidos por ella. Es indudable que se tratan de obligaciones que limitan la autoridad del Estado para imponer restricciones sobre los derechos protegidos.

La Corte Suprema de Justicia de la Nación, recuerda la operatividad de los tratados de derechos humanos y el carácter de fuente de interpretación que tienen las opiniones dadas por los órganos del sistema interamericano de protección de esos derechos. ${ }^{42}$

La Corte Interamericana de Derechos Humanos ha reafirmado que el ejercicio de la autoridad pública tiene límites que derivan de que los derechos humanos son atributos inherentes a la dignidad humana y, en consecuencia, superiores al poder del Estado y que el aparato estatal tiene la obligación de garantizarlos y de asegurar jurídicamente el libre y pleno ejercicio de aquellos. ${ }^{43}$

Derechos naturales, derechos públicos subjetivos, libertades públicas, derechos fundamentales son algunas de las nociones que parecen aproximarse a una idea común de lo que entendemos como derechos humanos. Desde un principio, ese término, expresa por lo menos dos cosas diferentes: una pretensión moral fuerte que debe ser atendida para hacer posible una vida humana digna y un derecho subjetivo protegido por una norma

\footnotetext{
40 Alli Aranguren Juan Cruz, Derecho administrativo y globalización, Edic. Thomson-Civitas, Madrid, 2004.

41 Díaz Elías, Estado de Derecho en Filosofía política Il. Teoría del Estado, Trotta, Madrid, 1996, p. 66.

42 Causa "Simón, Julio Héctor y otros s/ privación ilegítima de la libertad", voto del Dr-Ricardo L. Lorenzetti y Fallos 318:524.

43 Opinión Consultiva Corte Interamericana DH -OC-6/86.
}

A \& C R. de Dir. Administrativo \& Constitucional, Belo Horizonte, ano 8, n. 31, p. 150-179, jan./mar. 2008 
jurídica. ${ }^{44}$

Estos derechos son consecuencia -y por ende protegen-de la dignidad y existencia del ser humano, por lo que su violación no solo afecta al individuo sino a la sociedad en su conjunto. ${ }^{45}$

En su vínculo con la noción de bienestar general, debe considerarse que éste es el resultado de un interés que surge de la existencia de la vida en comunidad, en el cual los individuos pueden reconocer, también, un interés propio y directo.

El artículo 32.2 de la Convención Interamericana de Derechos Humanos incluye limitaciones inherentes a los derechos de todas las personas que resultan del convivir en una sociedad, indicando que no puede invocarse el "orden público" o el "bien común" como medios para suprimir un derecho garantizado por la Convención o para desnaturalizarlo o privarlo de contenido real.

El vínculo entre el bien común con el reconocimiento y goce de los derechos humanos, surge de una visión integradora, en la medida que la autoridad pública - en su carácter de custodia y promotora del bien común - debe hacer efectiva la vigencia de aquéllos.

Estamos, entonces, en presencia de una interacción entre derechos individuales e interés general, entre garantías y potestades; ámbito en el cual el Estado no puede instituirse como el único responsable de determinar el bien común, pero sí en su principal intérprete y realizador a partir de las necesidades y la participación de los particulares y de organizaciones comunitarias.

Rodríguez Arana-Muñoz ha indicado que "hoy por hoy la Administración no es la titular del interés público, sino que se define en una acción dinámica entre Poder público y agentes sociales...”. ${ }^{46}$

El reconocimiento expreso - y la protección efectiva-de derechos y garantías - permite afirmar que el interés público ya no es responsabilidad

\footnotetext{
44 Peces-Barba Martinez Gregorio, Curso de derechos fundamentales, Teoría general, Universidad Carlos III de Madrid, p. 21 y ss. y Muguerza Javiery otros, El Fundamento de los derechos humanos, Edit. Debate, Madrid, 1989.

45 Perez Luño señala que la dignidad humana supone "el valor básico fundamentador de los derechos humanos que tienden a explicar y satisfacer lasnecesidad de la persona en la esfera moral" Perez Luño Antonio E. "Derechos humanos. Estado de derecho y Constitución", Edit. Tecnos, Madrid, 1984, p. 49 y ss. Comparto las reflexiones de Zilli de Miranda en torno a que "(...) el Estado puede y debe actuar en función de su insoslayablecometido, atendiendo a los principales criterios de organización social en una democracia: igualdad de oportunidades materiales, justicia social,solidaridad y subsidiariedad", en "La solidaridad social en dos fallos del fuero contencioso administrativo, ED 21/08/2000, Supl. DerechoAdministrativo, p. 16.

${ }^{46}$ Rodríguez Arana Muñoz, Jaime, Etica, Poder y Estado, Ediciones RAP, Buenos Aires, 2004, p. 88.
} 
exclusiva de la Administración, pues ha cobrado protagonismo el usuario y el consumidor; la primacía de los tratados internacionales y la existencia de organismos supraestatales, supranacionales e internacionales. ${ }^{47}$

El correlato de este enfoque, es exigir que la Administración esté organizada en base a criterios de juridicidad, eficiencia y eficacia, y así constituirse en un instrumento idóneo para proteger los derechos y garantías y permitir su pleno ejercicio.

\section{La participación. Los Usuarios y Consumidores}

Participar implica ejercer acciones y prácticas con el objeto de contribuir a mejorar el funcionamiento de instituciones y a proteger los derechos y garantías individuales. Esta participación excede el interés particular de los ciudadanos, para ubicarse en el plano del interés público.

Rodríguez Arana Muñoz entiende que ella no sólo es un objetivo que debe seguirse (mayores posibilidades de participación de los ciudadanos en la cosa pública) sino también un método político. Hablar de la participación como método, implica una actitud abierta, una disposición hacia el público. Por eso, supone el reconocimiento de la dimensión social del individuo, la constatación de que sus intereses, preocupaciones trascienden su marco individual para extender a la sociedad en su conjunto. ${ }^{48}$

Conforme a este enfoque, solo es concebible la participación si se concreta en un contexto de libertad. Sin libertad no hay participación porque ésta implica la integración activa de la persona a la vida social. A esta condición se suma una dimensión ética, pues es el resultado de una opción, un compromiso, ya que supone "la asunción de un supuesto de que el bien de todos los demás es parte sustantiva del bien propio". ${ }^{49}$

En la República Argentina, esta metodología se ha asociado básicamente a dos tipos de actividades: a) la participación en organizaciones no gubernamentales que abogan ante el poder político (especialmente los poderes ejecutivos y legislativos) ejerciendo presión, b) la participación en los procesos de toma de decisiones del gobierno, mediante mecanismos

\footnotetext{
47 Salomoni Jorge L., Interés Público y Emergencia, Rev. Actualidad en el Derecho Público n. 18/20. Este profesor señala que "resulta necesario revisar los postulados sobre los que se construyó el derecho administrativo decimonónico, sobre todo, lo atinente a la relación jurídica emergente de tal ordenamiento. Ello implicará necesariamente, la reconstrucción del sistema de derecho de los particulares, de la sociedad y del de las potestades estatales."

48 Rodriguez Arana-Muñoz Jaime, La participación en la nueva ley de medidas para la modernización del gobierno local. ED, Suplemento de derecho administrativo 31/03/2004, p. 11. Acerca de la participación en los municipios ver Galli Guillermo M., La participación directa de los vecinos en el Gobierno de las autonomías municipales (una visión desde las constituciones provinciales) Revista RAP n. 302, Buenos Aires, 2003, p. 59.

49 Rodriguez Arana-Muñoz Jaime, La participación en la nueva ley..., op. cit.
} 
que permiten a la ciudadanía a expresarse en ese sentido y que, a veces, le otorgan el poder de decidir colectivamente sin intermediación alguna (audiencias públicas, referendum, plebiscito, iniciativa popular, etc.). ${ }^{50}$

En ese sentido, el artículo $42 \mathrm{CN}$ reconoce que:

Los consumidores y usuarios de bienes y servicios tienen derecho, en la relación de consumo, a la protección de su salud, seguridad e intereses económicos; a una información adecuada y veraz; a la libertad de elección, y a condiciones de trato equitativo y digno. (...) La legislación establecerá procedimientos eficaces para la prevención y solución de conflictos, y los marcos regulatorios de los servicios públicos de competencia nacional, previendo la necesaria participación de las asociaciones de consumidores y usuarios y de las provincias interesadas, en los organismos de control.

La Constitución Nacional ha precisado una garantía constitucional atribuida a los usuarios, ${ }^{51}$ considerados en su inserción en asociaciones, a cuya constitución proveerán las autoridades, que consiste en su participación necesaria en los organismos de control y en su legitimación procesal activa para reclamos de derechos de incidencia colectiva.

En la norma constitucional encuentra cabida, tanto los derechos de pertenencia común, colectiva, difusa, de una pluralidad de personas indeterminadas que se refieren a un bien único, indivisible y por tal no fraccionable (ambiente sano, equilibrado) como la protección a derechos e intereses que pertenecen a los particulares y así de objeto divisible, pero que su afectación adquiere una dimensión social incidiendo en intereses colectivos o generales. ${ }^{52}$

Ahora bien, el respeto de la participación ciudadana - y en particular de los usuarios y consumidores - debe traducirse necesariamente en una estructura adecuada de la Administración Pública, que haga posible la intervención de los ciudadanos.

Es destacable el contenido del Decreto del Poder Ejecutivo Nacional $\mathrm{n}^{\circ} 1.172 / 2003^{53}$ - con fundamento en los artículos 1, 22, 41, 42 y 75 inc. 22 de la Constitución Nacional - se aprobaron cinco Reglamentos Generales vinculados con el acceso a la información pública y la participación. ${ }^{54}$

50 Saba Roberto y Böhmer Martín, Participación Ciudadana en Argentina, Estrategias para el efectivo ejercicio de los derechos, el Dial.

51 Sostiene la doctrina que se es usuario sólo frente a la Administración pública, titular de la competencia para la prestación de un servicio u obra de utilidad común de que se trate. Barra, Rodolfo C., Contrato de obra pública, T. 1, Parte General. Consorcios. Concesión de obra pública, Buenos Aires, Ábaco, 1984, p. 346". En forma consecuente, el mismo texto constitucional ha distinguido perfectamente usuario de consumidor al brindarle al primero mayor grado de protección. Salomoni, Jorge Luis, Teoría General de los Servicios Públicos, Buenos Aires, Ad Hoc, 1999, p. 39.

52 Jeanneret de Perez Cortes Maria, La legitimación del afectado, del Defensor del Pueblo y de las Asociaciones, L.L. 2003-B. p. 133.

A \& C R. de Dir. Administrativo \& Constitucional, Belo Horizonte, ano 8, n. 31, p. 150-179, jan./mar. 2008 
Sin soslayar la importancia de todos los mecanismos implementados por esa norma; en particular hemos de referirnos a la audiencia pública en el ámbito de los servicios públicos - y que ya estaba contemplada en algunos marcos regulatorios anteriores a la reforma constitucional de 1994 - por constituir un medio de defensa del particular, de autocontrol administrativo e instrumento de colaboración y participación de los interesados, en el marco del "debido procedimiento adjetivo". ${ }^{55}$

La audiencia pública es: ${ }^{56}$ a) Una garantía objetiva de razonabilidad para el administrado en cuanto percepción de que el Estado actúarazonablemente; b) Una garantía objetiva de transparencia de los procedimientos estatales; c) Un mecanismo idóneo de formación de consenso de la opinión pública respecto de la juridicidad yconveniencia del obrar estatal; d) Un elemento de democratización del poder, conforme al clásico principio de que la democracia es no sólo unmodo de designación del poder, sino también un modo de ejercicio del poder; e) Un modo de participación ciudadana en el poder público, algo que viene exigido tanto por principios políticosy constitucionales como por las normas supranacionales.

La garantía de oír al interesado antes de dictar una decisión que pueda afectar sus derechos o intereses es un principio de raigambre constitucional. Y específicamente la audiencia pública encuentra su sustento en el artículo 42 de la Ley Fundamental, que exige que la legislación prevea "la necesaria participación de las asociaciones de consumidores y usuarios y de las provincias interesadas, en los organismos de control”.

La omisión de la Administración de realizarla configurará un vicio en el procedimiento del acto administrativo, acarreando la nulidad absoluta e insanable de éste, por violación de los artículos $7^{\circ}$, inciso d) procedimiento esencial y sustancial, e inciso e) -motivación; y 14, inciso b) -fulmina con la nulidad absoluta el vicio esencial de procedimiento, de la Ley $\mathrm{n}^{\mathrm{o}} 19.549 .{ }^{57}$

El concepto de esta institución tiene un doble carácter público: a) por la publicidad y transparencia del procedimiento, su oralidad e inmediación

\footnotetext{
53 B.0.04/12/2003.

54 Reglamentos Generales de: a) Audiencias Publicas para el Poder Ejecutivo Nacional, b) Publicidad de la Gestión de Intereses, c) Elaboración Participativa de Normas, d) Acceso a la Información Publica, e) Reuniones Abiertas de los Entes Reguladores de Servicios Públicos.

55 Comadira Julio R., Derecho Administrativo...op.cit., p. 249.

56 Gordillo Agustín, Tratado de Derecho Administrativo, T. II -XI-6, FDA, Buenos Aires.
}

A \& C R. de Dir. Administrativo \& Constitucional, Belo Horizonte, ano 8, n. 31, p. 150-179, jan./mar. 2008 
y registro gráfico y fílmico de los medios de comunicación, publicación de las reuniones, etc. y b) especialmente, por la participación procesal y el acceso del público en general a tales procedimientos, como sujeto activo y parte en sentido procesal de ellos.

Lo primero hace a la calidad necesariamente transparente y abierta al conocimiento público de todos los actos estatales; lo segundo es lo que cualifica de modo especial a las "audiencias públicas", y "es la activa participación del público como parte en el procedimiento, en sentido jurídico y no ya como mero 'espectador"”. ${ }^{58}$

\section{El Poder Ejecutivo y el Jefe de Gabinete de Ministros: División entre titularidad y gestión de la función administrativa. Los Ministros}

\section{El Poder Ejecutivo}

La Administración Pública es la organización que permite concretar las decisiones del Poder Ejecutivo; éste es su "conductor".

Los problemas surgen cuando la Administración funciona primordialmente al servicio personal del Poder Ejecutivo, traicionando su verdadera naturaleza vicarial. La historia nos muestra la simbiosis que se produce entre el Poder Ejecutivo, como líder político, y la Administración, cuando ésta pasa a convertirse en una herramienta a disposición de conductas demagógicas de poder.

La Constitución Nacional desde 1853 consagra el régimen presidencialista: un sistema de separación y equilibrio de los poderes, cuya rama ejecutiva está a cargo del Presidente de la República, asistido por ministros o secretarios por él designados, que actúan como ejecutores de la política presidencial y cuya permanencia en el caro depende de la voluntad y confianza del presidente.

Una de las características de este régimen, radica en la forma paternalista de ejercer las funciones presidenciales y con una fuerte personalización del poder en particular, en los países latinoamericanos. ${ }^{59}$

El sistema, concibe un Poder Ejecutivo monocrático, cuyo titular es elegido por el pueblo y no por el Legislativo, no está sometido al voto

\footnotetext{
${ }^{57}$ Uslenghi, Alejandro, Audiencias Públicas, en Procedimiento Administrativo, Edic. Ciencias de la Administración, Buenos Aires, 1998, p. 303.

58 Gordillo, Agustín, Tratado...op.cit.
} 
de desconfianza, y es Jefe de Estado y del Poder Ejecutivo - en contraposición al sistema parlamentario.

Recordemos que el Poder Ejecutivo en el esquema de la división de poderes de Montesquieu, es el poder "originario", que en sus comienzos abarcó todas las funciones estatales y que como consecuencia del reparto de poderes, se desprendió progresivamente de las actividades legislativa y judicial para terminar reteniendo la función ejecutiva. ${ }^{60}$

El vicepresidente no forma parte de este Poder; por ello se lo denomina un "órgano extra-poder". Sin embargo, si se lo considera en su calidad de presidente del Senado, ese carácter cambia por encontrarse "dentro" del Poder Legislativo. ${ }^{61}$

Las Jefaturas reconocidas en cabeza del Presidente son: ${ }^{62}$

La jefatura de Estado: Aunque la Constitución expresa que es el Jefe Supremo de la Nación, se refiere a la titularidad del Estado, pues en la semántica de la Constitución ambos términos se emplean como sinónimos. ${ }^{63}$ Ella implica la representación interna e internacional del Estado como persona jurídica y en su nombre negocia y firma los convenios internacionales. Ninguno de los otros dos poderes invisten esa jefatura, la que es excluyente.

La jefatura de Gobierno: es la cabeza de la Administración Pública y su responsable político, aunque el ejercicio lo tenga el Jefe de Gabinete. Es el responsable político de la Administración Pública. Fija en ese ámbito las políticas, objetivos y modos de alcanzarlos.

Por último le corresponde la Jefatura de las Fuerzas Armadas. ${ }^{64}$ Éstas deben estar subordinadas a la autoridad civil, que establece los objetivos estratégicos y tácticos y también dispone su movilización y eventual entrada en combate. La organización y funcionamiento de las Fuerzas Armadas corresponde al Congreso Nacional. La comandancia del Presidente es de naturaleza político-militar (aún que no necesariamente técnico militar) y administrativa. ${ }^{65}$

La reforma constitucional de 1994, no modificó la naturaleza uniper-

\footnotetext{
${ }^{59}$ Gross Espell Héctor, El predominio del Poder Ejecutivo en Latinoamérica en El predominio del Poder

${ }^{60}$ Bidart Campos Germán, Manual de la Constitución reformada, T. III, EDIAR S.A., Buenos Aires, 1999.

61 Bidart Campos, Germán, Manual de la Constitución reformada..., op.cit., p. 204.

${ }^{62}$ El inciso 1 del artículo 99 expresa "Es el jefe supremo de la Nación, jefe de gobierno y responsable político de la administración general del país".

${ }_{63}$ Gelli María Angélica, Constitución de la Nación...op.cit., p. 692.

${ }^{64}$ El inciso 12 del artículo 99 establece "Es comandante en jefe de todas las fuerzas armadas de la Nación".
} 
sonal de este órgano; sólo atenuó - aunque en mínima proporción — el sistema presidencialista. Un breve repaso de sus potestades, nos lleva a considerar que la reglamentaria es basilar del derecho público argentino. ${ }^{66}$ Los reglamentos previstos en la Constitución Nacional son: de ejecución o ejecutivos; autónomos; delegados y de necesidad y urgencia.

Los reglamentos de ejecución; previstos en el artículo 99 inc. 2; son los que el Ejecutivo dicta en ejercicio de facultades constitucionales propias con el objeto de asegurar la aplicación o ejecución de las leyes. Mediante éstos, se regulan los detalles necesarios para cumplir con las leyes y las finalidades del legislador. ${ }^{67}$

En el ejercicio de esa atribución, que corresponde exclusivamente al Presidente de la República Argentina, no puede alterar el espíritu de la ley. Los Reglamentos autónomos, son normas que dicta sobre materias que forma parte de la denominada "Zona de reserva de la Administración". Con su dictado se interpreta o aplica la Constitución directamente. Este tipo de reglamentos también pueden ser dictado por el Jefe de Gabinete de Ministros en uso de las facultades otorgadas por el artículo 100 de la Constitución o en materias que les fuera delegada por el Presidente.

Los reglamentos delegados, son normas que este Poder dicta en forma excepcional. En efecto, el artículo 76 de la Constitución Nacional prohibe la delegación legislativa del Congreso Nacional al Poder Ejecutivo; salvo en materia de emergencia pública o de Administración. La delegación está sujeta a límites: el Poder Legislativo debe fijar un plazo para su ejercicio y las bases de la delegación, es decir la política legislativa.

Por último los decretos de necesidad y urgencia previstos en el artículo 99 inciso 3 a partir de la reforma constitucional, se dictan en circunstancias excepcionales que hicieran imposible seguir el procedimiento normal de la sanción de las leyes y siempre que no verse sobre materia penal, tributaria, electoral o el régimen de los partidos políticos.

\section{Jefe de Gabinete de Ministros}

La institución de Jefe de Gabinete de Ministros, fue incorporado por la reforma constitucional de 1994. Las primeras tendencias políticas pretendieron aproximarse a los sistemas que adjudican la función de gobernar

\footnotetext{
65 Gelli María Angélica, Constitución de la Nación...op.cit., p. 720/721.

${ }^{66}$ Cassagne Juan Carlos, Potestad reglamentaria y reglamentos de necesidad y urgencia en XXIX Jornadas Nacionales de Derecho Administrativo, RAP, 2003, p. 47 y ss.

67 Marienhoff Miguel, Tratado de derecho administrativo, Abeledo Perrot, Buenos Aires, 1990, T. I, p. 248.
} 
y de administrar a un Primer Ministro y que, correlativamente reservan la jefatura del Estado al Presidente, o al Monarca según los casos. ${ }^{68}$

La Argentina no implementó ni un sistema parlamentarista ni semiparlamentarista, en realidad la presencia del Jefe de Gabinete de Ministros y sus relaciones con el Poder Ejecutivo se aproximan más a una desconcentración de funciones o a una delegación impropia.

La incorporación a la organización administrativa de este funcionario, pretendió ser una limitación del poder presidencial, aunque la letra de la Constitución nos muestra una realidad distinta a las pretensiones originarias. ${ }^{69}$

Tanto el nombramiento del Jefe de Gabinete como su remoción, son atribuciones del Presidente, pero puede ser interpelado por las Cámaras del Congreso Nacional, para una moción de censura y ser removido por el voto de la mayoría absoluta de cada una de ellas. ${ }^{70}$

Lo cierto es que la reforma constitucional ha pretendido separar la titularidad del ejercicio de la función administrativa, aún cuando el Presidente sigue dictando ciertos actos propios de esa actividad.

La doctrina ha debatido con empeño sobre esta cuestión, en particular cuando ha debido dilucidar los vínculos con el Presidente y con los Ministros. ${ }^{71}$

Excede el presente analizar las posturas doctrinarias; baste con indicar que conforme a los artículos 99 y 100 de la Constitución y a la Ley de Ministerios, 22.520 (t.o. 438/92), el Jefe de Gabinete se encuentra subordinado al Poder Ejecutivo y por lo tanto éste puede delegarle ciertas facultades y avocarse a otras, siempre que éstas no hayan sido atribuidas por el constituyente en forma exclusiva al Jefe de Gabinete - por ejemplo su intervención en el dictado de decretos de necesidad y urgencia - o que la avocación no implique anular la actuación de aquel funcionario.

En cuanto a su relación con los Ministros, a contrario de lo que sostiene destacada doctrina como Julio Rodolfo Comadira, la Procuración del

\footnotetext{
68 Cassagne Juan Carlos, Derecho Administrativo...op.cit., p. 26

69 Ver Ivanega Miriam, Principios de Administración Pública, Ábaco, Buenos Aires, 2005, Cap. V.

70 Para que resulte viable una moción de censura, no es necesario que existan algunas de las causales de procedencia del juicio político, es decir se lo puede remover sin imputarle la comisión de un delito en el ejercicio de sus funciones. Tampoco resulta necesario contar con las mayorías parlamentarias del juicio político. El juicio político en cambio es un proceso jurisdiccional en el cual es necesario acreditar las causales establecidas en la Constitución Nacional y el respeto del derecho de defensa. Debe contar con dos tercios de los votos de los miembros de cada una de las cámaras.

71 Ver Ivanega Miriam M., Principios...op.cit, p. 187 y ss.
} 
Tesoro de la Nación entiende que pese a la denominación Jefe de Gabinete de Ministros y de ciertas competencias contenidas en el texto constitucional, ese órgano es "uno más entre los Departamentos de Estado regulados por los arts. 102 a 107 de la Ley Fundamental (...) no cabe interpretar la existencia de una jerarquía de éste sobre los demás 'ministros secretarios' de conformidad con lo prescripto por el artículo100 de la Constitución Nacional". ${ }^{72}$

Así, no tiene atribuida relación de supremacía alguna que lo faculte a modificar, anular o sustituir decisiones adoptadas por los demás Ministros en ejercicio de sus propias competencias. Por eso es el Presidente de la Nación el órgano competente para resolver los recursos jerárquicos interpuestos contra las resoluciones de los Ministros.

Siguiendo esa línea de razonamiento, el Jefe de Gabinete tampoco puede ejercer control de tutela sobre las entidades descentralizadas; sólo le corresponde al Poder Ejecutivo, en calidad de Jefe de la Administración Pública y por imperio del artículo 99 inc. 1 de la Constitución Nacional.

Si bien el marco general lo brinda la Constitución Nacional, el plexo normativo que fija las atribuciones del Jefe de Gabinete de Ministros comprende además la ley de ministerios (ley no 22.520 -T.O.438/92) y sus normas complementarias y reglamentarias), las leyes de presupuesto, la ley $n^{\circ} 11.672$ y el decreto 577/2003.

El ejercicio de la administración general del país involucra diversas facultades:

1. Emisión de actos y reglamentos en ejercicio de sus propias facultades o de las delegadas por el Presidente de la Nación (inciso 2 del artículo 99 CN e inciso 8 del artículo 16 ley n $\left.{ }^{\circ} 22.520\right)$

2. Organización de la Administración Pública, que involucra su funcionamiento, el nombramiento de sus empleados, ${ }^{73}$ la definición de políticas de recursos humanos, la aprobación de estructuras (inciso 3 del articulo $99 \mathrm{CN}$ e incisos 5, 9, 10, 11, 12, 16, 25, 27 del artículo 16 ley $\mathrm{n}^{\mathrm{o}} 22.520$, artículo 1 del decreto $\left.\mathrm{n}^{\mathrm{o}} 577 / 2003\right)^{74}$

3. De gabinete (inciso 5 del artículo $99 \mathrm{CN}$ e inciso 4 del artículo 16

\footnotetext{
2 Dictámenes 221.133 y 222:53.

73 Teniendo en cuenta las facultades constitucionales del Presidente de la Nación, el Jefe de Gabinete puede nombrar y remover al personal de la Administración jerarquizado o no, con excepción de: 1) oficiales de las secretarías del Presidente; 2) miembros de las fuerzas armadas, 3) miembros del cuerpo diplomático y consular, 4) jueces de los tribunales federales, 5) ministros, 6) funcionarios políticos (por ejemplo: secretarios y subsecretarios de Estado).
}

A \& C R. de Dir. Administrativo \& Constitucional, Belo Horizonte, ano 8, n. 31, p. 150-179, jan./mar. 2008 
ley $\left.\mathrm{n}^{\mathrm{O}} 22.520\right)$

4. Presupuestarias (inciso 7 del artículo $99 \mathrm{CN}$ e incisos 15, 21 del artículo 16 ley $\left.\mathrm{n}^{\circ} 22.520\right)$

5. Vinculadas con el Poder Legislativo (inciso 6, 9, 10, 11 artículo 99 y artículo $101 \mathrm{CN}$ e incisos 6, 7, 13 del artículo 16 ley $\mathrm{n}^{\mathrm{o}} 22.520$ )

6. Refrendo de actos y reglamentos (inciso 8, 12, 13 artículo 99 CN). El artículo 100 de la Constitución Nacional indica que le corresponde el refrendo de: a) los decretos reglamentarios de las leyes, los decretos que disponen la prórroga de las sesiones ordinarias del Congreso o la convocatoria a extraordinarias y los mensajes presidenciales que promuevan iniciativa legislativa, ${ }^{75} \mathrm{~b}$ ) los decretos que ejercen facultades delegadas por el Congreso, los que estarán sujetos al control de la Comisión Bicameral Permanente ${ }^{76}$ y c) conjuntamente con los demás ministros, los decretos de necesidad y urgencia y los que promulgan parcialmente leyes. ${ }^{77}$

\section{Los Ministros}

No obstante que la organización del Poder Ejecutivo sigue el régimen presidencialista de los Estados Unidos; en la caracterización del instituto ministerial se ha utilizado el modelo europeo, con una función de colaboración respecto al titular de aquel Poder. ${ }^{78}$

Los ministerios tienen una doble función: de especialización y de integración. De especialización porque a través de ellos se diversifica la actividad administrativa estatal; y de integración porque son el cauce para reconducir a unidad la enorme variedad de órganos a que lleva el principio de la división del trabajo. ${ }^{79}$

La relación de los ministros con el Presidente deriva de la Constitución Nacional; aquel los nombra y remueve. Si bien el Poder Legislativo debe dictar la ley de ministerios, lo hace para fijar el número y repartir la

\footnotetext{
${ }^{74}$ Este decreto aprueba las contrataciones encuadradas en las previsiones del Decreto No 491/02 y su reglamentación en aquellos supuestos en los que se pacte una retribución mensual u honorario equivalente superior a la suma de pesos dos mil (\$2.000.-). Se incluyen los contratos de locación de servicios personales celebrados en virtud de lo dispuesto por el decreto 1184/01, los contratos de locación de obra intelectual prestados a título personal encuadrados en los decretos $1023 / 01$ y 436/00 y los contratos regidos por la Ley $N^{\circ} 25.164$, como así también los convenidos para proyectos o programas de cooperación técnica con financiamiento bilateral o multilateral, nacional e internacional.

${ }^{75}$ Artículo 100, inc. 8).

${ }^{76}$ Artículo 100, inc. 12)

${ }^{77}$ Artículo 100, inc. 13)

${ }^{78}$ Linares Quintana Segundo V. Tratado Ciência...op.cit., p. 632.

${ }^{79}$ Entrena Cuesta, Rafael, Curso de derecho administrativo, Edit. Tecnos, Madrid 1995, 11. ed., V.I/2... p. 100.
}

A \& C R. de Dir. Administrativo \& Constitucional, Belo Horizonte, ano 8, n. 31, p. 150-179, jan./mar. 2008 
competencia entre los órganos ministeriales, pero no puede interferir en la relación de éstos con el Presidente. ${ }^{80}$

Las atribuciones ministeriales son: a) políticas, de naturaleza ejecutiva principalmente (la representación política y parlamentaria de su departamento); b) administrativas, que pueden ser de carácter jurídico-representativas de la Nación, de organización y dirección, de estudios y tramitación de asuntos administrativos.

Frente al Poder Ejecutivo tienen un carácter político, con un doble tipo de relación: a) el refrendo, b) las reuniones de gabinete.

En cambio frente a sus respectivos ministerios prevalece el aspecto administrativo, pues ejercen la jefatura, dirección, control, superintendencia y manejan el régimen económico-financieros de sus respectivos departamentos. Los actos que dicta en ese carácter no son actos del Poder Ejecutivo sino ministeriales.

Ante el Poder Legislativo, la Constitución Nacional prevé la concurrencia del ministro al Congreso con tres modalidades: a) llamamiento por cada cámara a efectos de que proporcionen explicaciones e informes: ${ }^{81}$ b) concurrencia espontánea a las sesiones del Congreso, en las que participen en debates pero $\sin$ voto $^{82} \mathrm{c}$ ) presentación obligatoria de una memoria detallada del estado de los negocios en sus departamentos ministeriales. ${ }^{83}$

\section{Los Entes Reguladores de servicios públicos}

Solamente hemos de señalar que la reforma constitucional incorporó la obligación de dictar los marcos regulatorios de los servicios públicos; en los términos del artículo 42 CN ya indicados. En el caso de la República Argentina, los entes reguladores son anteriores a la Reforma del Estado de 1989, aunque se desarrollaron con más intensidad desde ese momento.

Señala Entrena Cuesta señala que si bien el número de departamentos ministeriales varía en cada Estado, existen rasgos comunes a los diversos ordenamientos, pues todo Estado necesita preocuparse por las relaciones con los otros Estado, atender sus necesidades internas y conseguir los medios para alcanzar sus fines. "Y esas dos últimas grandes secciones de la actividad estatal se subdividen a su vez en dos partes completamente diversas: los fines a conseguir pueden depender de la idea de tutela jurídica o de la injerencia social, y los medios necesarios para alcanzarlos pueden consistir en la fuerza armada o los medios económicos" p. 100

80 La vigente Ley de Ministerios N²2.520 -t.o. 438/92-y sus modificaciones, contempla diez (10) Ministerios: 1) Interior, 2)Relaciones Exteriores, Comercio Internacional y Culto, 3) Defensa, 4) Economía y Producción,

5) Planificación Federal, Inversión Pública y Servicios, 6) Justicia, Seguridad y Derechos Humanos, 7) Trabajo,

Empleo y Seguridad Social, 8) Desarrollo Social, 9) Salud y 10) Educación, Ciencia y Tecnología.

81 Artículo 71.

82 Artículo 106

83 Artículo 104. 
A comienzos de 1990, muchos de estos entes se encontraban en funcionamiento, algunos de los cuales fueron disueltos por el Poder Ejecutivo Nacional mediante decreto $\mathrm{n}^{\mathrm{o}} 2.284 / 91 .^{84}$

En párrafos anteriores se transcribió el artículo 42 que indica que la legislación establecerá los marcos regulatorios de los servicios públicos de competencia nacional.

En la República Argentina estos entes, en general, tienen naturaleza autárquica o descentralizada. Sin embargo, la doctrina no es uniforme respecto al Poder competente para crear estos organismos. Algunos propician la creación por parte del Ejecutivo; otros del Legislativo y un tercer enfoque aboga por las facultades concurrentes.

En realidad, el conflicto se plantea respecto a la interpretación que cabe asignar al término "legislación" expresado en el citado artículo constitucional. En una posición extrema se ubica Gordillo, para quien la facultad de disponer la creación de un ente autárquico corresponde al Congreso nacional. ${ }^{85}$ El fundamento radica en las atribuciones del Poder Legislativo según el artículo 75 inciso 20 de la Constitución Nacional que consagra la facultad de ese Poder para crear y suprimir empleos y fijar atribuciones. ${ }^{86}$ El citado autor, enseña que el artículo 42 de la Constitución Nacional, al referirse en su texto a la "legislación", obliga en protección de los usuarios, a que los entes sean creados por ley del Congreso Nacional en ejercicio de facultades constitucionales exclusivas, lo que deriva en la improcedencia de la intervención, la avocación y el control por recurso de alzada por parte del Poder Ejecutivo. ${ }^{87}$

Otro sector concluye que el artículo 42 de la Constitución Nacional no exige que se trate de una ley en sentido formal, sino en sentido material,

\footnotetext{
${ }^{84}$ Los anexos I y II del decreto mencionan a los siguientes organismos: Junta Nacional de Granos; Junta Nacional de Carnes; Instituto Forestal Nacional; Mercado de Concentración Pesquera; Instituto Nacional de la Actividad Hípica; Corporación Argentina de Productores de Carne; Mercado Nacional de Hacienda de Liniers; Comisión Reguladora de la Producción y Comercio de la Yerba Mate; Mercado Consignatario Nacional de Yerba Mate; Dirección Nacional del Azúcar.

85 Gordillo Agustín, Tratado...., T. I, op.cit., p.XI-5, Diez Manuel Derecho..., T. I, op.cit., p. 142, Bielsa Rafael, Derecho Administrativo, Depalma, Buenos Aires, 1964.

${ }^{86}$ Marienhoff en contra de esta posición entiende que no debe confundirse la creación de empleos con la de entidades autárquicas, pues el empleo no presupone personalidad jurídica, ni la existencia de un patrimonio, (elementos éstos que resultan fundamentales para la existencia de las entidades autárquicas) Marienhoff Miguel, Tratado..., op.cit., p.633 y ss. Cassagne contesta a ello que el verdadero motivo por el cual no puede aceptar esta tesis radica en que "si la creación de una entidad autárquica supone una limitación en las facultades de control del Ejecutivo que quedaría restringido a la legitimidad, excluida la oportunidad) ello no podría hacerse sin alterar lo prescripto en el artículo 99, inciso $1^{\circ}$, de la Constitución Nacional, ya que, en tal supuesto, la plenitud de la relación jerárquica aparecería afectada por un acto del Órgano Legislativo”. Cassagne Juan C., Derecho administrativo..., op.cit., p. 343.
} 
por lo tanto resultaría posible que un ente fuera creado por reglamento administrativo. No obstante ello, frente a la afectación de los derechos particulares deberían ser creados por ley formal. ${ }^{88}$

Finalmente, nos encontramos con los enfoques que se basan: a) en la zona de reserva de la Administración y que por lo tanto es competencia del Poder Ejecutivo, y b) en las facultades concurrentes que postula que la descentralización dispuesta por el Poder Ejecutivo puede operarse, pero postergarse su organización y actuación al momento de la aprobación del presupuesto por el Congreso nacional. ${ }^{89}$

Lo cierto es que estos entes no tienen en el sistema argentino un tratamiento constitucional que autorice a categorizarlos como órganos extrapoderes, por ello cuando por vía legislativa o jurisprudencial se aumentan en forma excesiva la discrecionalidad en el ejercicio de sus competencias "se conspira contra principios políticos y económicos esenciales del Estado de derecho". ${ }^{90}$

Si bien cumplen una función esencial en materia regulatoria, sus atribuciones, en atención al carácter autárquico, son esencialmente de naturaleza administrativa, sin perjuicio de "que en su creación debe acordarse cierta participación elemental al órgano legislativo teniendo en cuenta el tipo de funciones que habitualmente puede ejercer — sancionatorias, limitaciones administrativas a la propiedad, imposición de tasas un marco definido de control de tutela por parte del órgano ejecutivo y un control judicial amplio de la razonabilidad económica de su accionar". ${ }^{91}$

Actualmente, existen marcos regulatorios establecidos por ley y otros por decreto del Poder Ejecutivo. ${ }^{92}$ Las funciones establecidas por las normas de creación son: de regulación, fiscalización o control; sancionatorias; asesoramiento y resolución de conflictos.

\section{Organismos de control de la Administración Pública previstos}

\footnotetext{
${ }^{87}$ Gordillo, Agustín, Tratado..., T. I, op. cit; XV-1 y ss.

88 Ver Bianchi Alberto, La regulación...op.cit.; Comadira Julio R., Derecho administrativo...op.cit.; Aguilar Valdez Oscar, Apuntes....op.cit.. Este último autor aclara que no resultaría posible que bajo el argumento de la creación por el legislador se viera restringida la facultad del Poder Ejecutivo de controlar las decisiones del ente; no pudiendo restringirse o eliminarse la procedencia del recurso de alzada.

${ }^{89}$ Miguel Marienhoff es representante del primer criterio y Juan Carlos Cassagne del segundo.

90 Cuadros, Oscar A., "Los entes reguladores y el principio de la división de poderes", II Jornadas Internacionales Sobre Servicios Públicos, Universidad Austral -Universidad Católica De Cuyo, Facultad de Derecho, Mendoza, 2001, p. 153/162

91 Cuadros, Oscar A., "Los Entes Reguladores...op. y p.cit.. Alberto Bianchi indica que existen dos criterios para categorizar a los entes reguladores: a) uno amplio; que considera como ente regulador a todo aquel creado
} 


\section{en la Constitución Nacional}

\section{La AGN}

El artículo 85 de la Constitución establece:

El control externo del sector público nacional en sus aspectos patrimoniales, económicos, financieros y operativos, será una atribución propia del Poder Legislativo. El examen y la opinión del Poder Legislativo sobre el desempeño y situación general de la administración pública estarán sustentados en los dictámenes de la Auditoría General de la Nación. Este organismo de asistencia técnica del Congreso, con autonomía funcional, se integrará del modo que establezca la ley que reglamenta su creación y funcionamiento, que deberá ser aprobada por mayoría absoluta de los miembros de cada Cámara. El presidente del organismo será designado a propuesta del partido político de oposición con mayor número de legisladores en el Congreso. Tendrá a su cargo el control de legalidad, gestión y auditoría de toda la actividad de la administración pública centralizada y descentralizada, cualquiera fuera su modalidad de organización, y las demás funciones que la ley le otorgue, Intervendrá necesariamente en el trámite de aprobación o rechazo de las cuentas de percepción e inversión de los fondos públicos.

La incorporación de la Auditoría General de la Nación en el texto constitucional, se enrola en la tendencia de jerarquizar el control para lograr una mayor transparencia en la gestión pública. Se confiere ese reconocimiento, reafirmando la autonomía otorgada por la Ley $\mathrm{n}^{\circ} 24.156$

La AGN fue creada con anterioridad a la reforma constitucional de 1994, por la ley no 24.156 de Administración Financiera y Sistemas de Control, cuyo Título VII, regulando sus atribuciones y conformación. La referida ley no ha perdido vigencia, la que se aplica en armonía con el Constitución.

El fin del constituyente fue la de fortalecer la función de control propia del Congreso Nacional dotándola de un órgano técnico idóneo para ese cometido. Por ello, este tipo de órgano retroalimenta la tarea de legislador.

La inserción del órgano de control externo en el ámbito del Poder Legislativo, deviene del principio de división de poderes, que lleva ínsito

por ley o por decreto, bajo alguna forma descentralizada, que regula una actividad determinada, haya sido o no declarada como servicio público y b) restringido que reúne, a su vez, distintos enfoques: entes que sólo regulan la prestación de servicios públicos; que ordenan una actividad industrial; que ejercen una actividad jurisdiccional previa y obligatoria y pueden actuar como tribunales administrativos; los que fueron creados por ley del Congreso; entes que aparecieron luego de la reforma del Estado, etc.. Bianchi, Alberto, La regulación... op.cit, p. 223/224.

92 Los entes del gas y la electricidad se crearon por ley; el del agua y desagües cloacales estuvo previsto en el Anexo I de la ley 23.696, habiendo sido creado por convenio aprobado por Decreto n 999/92; la Comisión Nacional de Comunicaciones y la Comisión Nacional de Regulación del Transporte tuvieron su origen en un decreto del Poder Ejecutivo Nacional.

A \& C R. de Dir. Administrativo \& Constitucional, Belo Horizonte, ano 8, n. 31, p. 150-179, jan./mar. 2008 
la concepción del control recíproco entre ellos. De esta forma, y a fines de contrapesar el actuar del Poder Ejecutivo, el Legislativo ejerce un control sobre su actividad administrativa.

En realidad en el esquema normativo aplicable, encontramos que en sentido estricto, el órgano de control externo es el Congreso Nacional, y la AGN su asistente.

La intervención de este órgano, a los efectos de la acción de control del Congreso es obligatoria, aunque no vinculante, en consecuencia, el Congreso, por limitación constitucional, no podría emitir ninguna opinión, ni siquiera iniciar el procedimiento de examen de la actuación de la Administración pública, sin la previa intervención de la Auditoría General de la Nación, que se convierte así en un órgano esencial en el procedimiento del control legislativo. ${ }^{93}$

La autonomía funcional le permite ejercer su función técnica de control sin que puedan ser intervenida por el Congreso Nacional; así como dictar su propio reglamento de funcionamiento interno sin necesidad que deba ser ratificado por éste. ${ }^{94}$

El carácter o índole de la actividad desarrollada por la Auditoria, es esencialmente administrativa - técnica - y consultiva, de lo cual deriva que la ley ha pretendido privilegiar la función fiscalizadora por sobre la tradicional asignación de facultades jurisdiccionales. ${ }^{95}$

El control que ejerce es posterior, mediante la técnica de la auditoría. Carece de facultades jurisdiccionales para deslindar las responsabilidades de los funcionarios públicos y de atribuciones para aplicar multas y formular observaciones con carácter suspensivo.

Actualmente el órgano de conducción está conformado por un Presidente y seis Auditores Generales: tres designados por la Cámara de Senadores y tres por la Cámara de Diputados, de acuerdo a la composición política de cada cámara. Su mandato es de ocho años y se renuevan por mitades cada cuatro.

El Presidente es designado a propuesta del partido político de la oposición con mayor número de legisladores en el Congreso, conforme al artículo $85^{\circ}$ del texto cosntitucional. De ello se destaca que la Constitu-

\footnotetext{
93 Barra Rodolfo, El control de la Auditoría General de la Nación, Conferencia brindada el 16 de mayo de 2002, Jornadas sobre Control de la Administración Pública, Universidad Austral. Buenos Aires.

${ }^{94}$ Quiroga Lavié Humberto, Constitución de la Nación Argentina Comentada, 2. ed. actualizada, Editorial Zavalía, Buenos Aires, 1997, op.cit., p. 541.

95 Mertehikian Eduardo, "Algunas consideraciones acerca del control parlamentario del Sector Público Nacional" en Homenaje al Profesor Miguel S.Marienhoff - Obra colectiva -, Editorial Abeledo Perrot, Buenos Aires, 1998.
} 
ción ha querido poner en evidencia la influencia del principal partido de oposición en la conducción superior de este organismo. ${ }^{96}$

\section{b El Defensor del Pueblo}

En la República Argentina en el ámbito nacional, la primera regulación fue la Ley 24.284; sin perjuicio de que en el orden provincial y municipal actuaban organismos con funciones similares por ejemplo en Córdoba, San Luis, San Juan, Santa Fe y en las ciudades de Buenos Aires, La Plata, Posadas, Chilecito y La Banda. ${ }^{97}$

Posteriormente, en el año 1994, se lo incorpora a la Constitución Nacional.

El artículo 86 establece:

El Defensor del Pueblo es un órgano independiente instituido en el ámbito del Congreso de la Nación, que actuará con plena autonomía funcional, sin recibir instrucciones de ninguna autoridad. Su misión es la defensa y protección de los derechos y humanos y demás derechos, garantías e intereses tutelados en esta Constitución y las leyes, ante hechos, actos u omisiones de la Administración; y el control del ejercicio de las funciones administrativas públicas. El Defensor del Pueblo tiene legitimación procesal. Es designado y removido por el Congreso con el voto de las dos terceras partes de los miembros presentes de cada una de las Cámaras. Goza de las inmunidades y privilegios de los legisladores. Durará en su cargo cinco años, pudiendo ser nuevamente designado por una sola vez. La organización y el funcionamiento de esta institución serán regulados por una ley especial.

A su vez, el artículo $43 \mathrm{CN}$, le reconoce legitimación para interponer acción de amparo “(...) contra cualquier forma de discriminación y en lo relativo a los derechos que protegen al ambiente, a la competencia, al usuario y al consumidor, así como a los derechos de incidencia colectiva en general...".

El Defensor del Pueblo es un órgano unipersonal, creado en el ámbito del Poder Legislativo, independiente, con autonomía funcional y que no recibe instrucciones de ninguna autoridad. Se ha entendido que éstos

\footnotetext{
96 Barra, Rodolfo, El rol de las Instituciones..., op.cit., p.14. Barra señala que "la previsión constitucional de asegurar al principal partido de oposición la conducción de la Auditoría tiene poco efectos prácticos, ya que podría ocurrir que el partido del Gobierno tuviese, a la vez, mayoría en ambas Cámaras (...) con lo cual el oficialismo contaría con cuatro propuestas o designaciones y la oposición con tres, es decir, aún cuando el presidente es designado a propuesta de la principal oposición, la conducción efectiva de la Auditoría quedaría en manos del oficialismo. Es ésta una anomalía que la nueva ley orgánica debería corregir" op.cit., p. 15.

97 Canosa Armando, El Defensor del Pueblo y el control de la Administración, en Control de la Administración Pública (administrativo, legislativo y judicial) Edic. RAP; Buenos Aires, 2003, p...
} 
resultan términos que deben ser entendidos en su conjunto y que tienen relación con la libre actuación del Defensor en procura de los objetivos perseguidos para su creación. ${ }^{98}$

La competencia del organismo es amplia pues abarca tanto la defensa y protección de los derechos humanos y demás derechos, garantías e intereses - tutelados en la Constitución y en las leyes ante hechos, actos u omisiones de la Administración - como el control del ejercicio de las funciones administrativas públicas.

En cuanto a su legitimación procesa ${ }^{99}$ se trata de una legitimación es anómala, extraordinaria o diferente a la general. ${ }^{100} \mathrm{Su}$ particularidad se centra en que el derecho de acción es ejercido en nombre propio, pero a efectos de defender un derecho, garantía o interés cuya titularidad resulta ajena al actor. ${ }^{101}$ En estos casos, la legitimación ad causam no se identifica necesariamente con la titularidad de la relación de fondo.

La jurisprudencia tampoco es uniforme respecto al reconocimiento de legitimación procesal del Defensor del Pueblo. Si bien los tribunales de primera y segunda instancia son proclives a admitir con amplitud el acceso a la justicia de aquel funcionario, la Corte Suprema de Justicia de la Justicia, por el contrario, ha limitado su actuación.

En realidad, el artículo 86 CN debe ser interpretado a la luz del artículo $43 \mathrm{CN}$, de forma tal de no cercenar la competencia asignada en aras de la efectiva vigencia de los derechos y garantías fundamentales.

\section{El presupuesto}

El presupuesto público es un instrumento de programación económica y social, de gobierno, de administración y un acto legislativo.

Despliega toda su eficacia jurídica respecto de los gastos públicos. La esencia de la institución presupuestaria reside en su doble carácter de autorización y límite al Poder Ejecutivo para poder realizar gastos públicos.

Es un instrumento básico de la organización político-administrativa

\footnotetext{
98 Canosa Armando, El Defensor del Pueblo...op.cit.

99 Ver Creo Bay, Horacio D.; La vista de las actuaciones ante el defensor del pueblo, LL, T. 1996 - D, p. 75: Spota, Alberto; El defensor del pueblo, ED, T. 170, p. 986; Quiroga Lavié, Humberto; Nuevos órganos de control en la Constitución: El Defensor del Pueblo y el Ministerio Público, en La Reforma de la Constitución, Rubinzal Culzoni, Santa Fe, 1994, p. 267: Gozaini, Osvaldo Alfredo; Legitimación procesal del defensor del pueblo (Ombudsman), LL, T. 1994-E, p. 1376; Maiorano, Jorge Luis; El Ombudsman, T. I a IV, Ediciones Macchi, Buenos Aires, 1999.

100 Jeanneret de Pérez Cortes, María "La legitimación del Afectado, del Defensor del Pueblo y de las Asociaciones. La reforma constitucional de 1994 y la jurisprudencia" LL 2003-B-1333.

${ }^{101}$ Ver Verbic Francisco, La (negada) legitimación activa del Defensor del Pueblo de la Nación para accionar en defensa de derechos de incidencia colectiva. Buscando razones a la doctrina de la Corte Suprema en $<$ www. eldial.com>. suplementos derecho procesal.
} 
de la Nación, por lo cual una parte del éxito de un gobierno se puede medir de acuerdo a la capacidad y habilidad que posea para realizar con eficiencia los procesos vinculados con la obtención, asignación y uso de los recursos públicos.

En él se reflejan las relaciones entre política y administración; pues tanto el contenido del gasto público como la forma de obtener los ingresos públicos, son decisiones políticas que deben responder a las necesidades sociales y que una vez plasmadas en el presupuesto se concretan mediante acciones ejecutadas por la Administración.

El presupuesto es una manifestación de la autonomía financiera estatal, un cauce de colaboración entre el Ejecutivo y el Legislativo y un instrumento de este poder sobre el primero.

El Congreso Nacional al tratar el proyecto de ley de presupuesto - en las comisiones parlamentarias y luego en las sesiones de sus dos Cámaras-que le remite el Poder Ejecutivo, despliega una función que, más allá de sus implicancias políticas, se convierte en una actividad de control respecto del plan de acción estatal para el ejercicio siguiente y de las políticas que el Ejecutivo aplicará para hacer efectivo ese plan. Por eso la aprobación del presupuesto, tanto a nivel nacional, provincial como municipal es un instrumento de contralor indispensable.

En la República Argentina, el Poder Ejecutivo prepara el proyecto de ley de presupuesto, el Congreso lo sanciona y el Jefe de Gabinete lo ejecuta.

La Constitución Nacional regula:

- artículo $4^{\circ}$ : es obligación, del Gobierno Federal, proveer los gastos de la Nación, indicando las principales fuentes del financiamiento (derechos de importación, exportación, venta o locación de tierras de propiedad nacional, renta de Correos, demás contribuciones que en forma equitativa y proporcional imponga el Congreso nacional y empréstitos y operaciones de crédito para urgencias nacionales

- artículo 16: la igualdad como base de los impuestos y cargas públicas -artículo 17: sólo el Poder Legislativo es el que autoriza a imponer las contribuciones del artículo 4 -artículo 52: corresponde a la Cámara de Diputados la iniciativa sobre contribuciones -artículo $75^{\circ}$ : Es competencia del Congreso nacional inc. 1. establecer los derechos de importación y exportación; inc. 2. imponer las contribuciones indirectas en forma concurrente con las provincias. Imponer las directas, por tiempo determinado y proporcionalmente iguales en todo el territorio nacional. Debe dictar la ley convenio que instituya los regímenes de coparticipación de esas 
contribuciones; inc. 3. establecer y modificar asignaciones específicas de recursos participables; inc. 4. contraer empréstitos; inc. 7. arreglar el pago de la deuda interior y exterior del a Nación; inc. 8. fijar anualmente el presupuesto general de gastos y cálculo de recursos de la Administración Pública Nacional y aprobar o desechar la cuenta de inversión; inc. 9. acordar subsidios del Tesoro Nacional a las provincias.

- artículo 99º , el Presidente de la Nación según el inc. 10 supervisa al Jefe de Gabinete de Ministros respecto de la recaudación de las rentas nacionales y de su inversión, es decir de la ejecución presupuestaria - artículo $100^{\circ}$ : al Jefe de Gabinete corresponde inc. 6 enviar al Congreso nacional el proyecto de ley de presupuesto; inc. 7, llevar a cabo su ejecución

Informação bibliográfica deste texto, conforme a NBR 6023:2002 da Associação Brasileira de Normas Técnicas (ABNT):

MABEL IVANEGA, Miriam. La Constitución Nacional y su incidencia en la organización de la Administración Pública Nacional en la República Argentina. A\&C Revista de Direito Administrativo e Constitucional, Belo Horizonte, ano 8, n. 31, p. 150-179, jan./mar. 2008. 